\title{
POR DETRÁS DO VÉU DA MULHER IRANIANA
}

Rosicler Santos ${ }^{1}$

RESUMO

A República Islâmica do Irã está na pauta do dia das discussões em todo o mundo. Desde que começou a crise nuclear iraniana, no ano de 2005, os olhos atentos do mundo todo se voltaram para este país do Oriente Médio, situado entre o Mar Cáspio e o Golfo Pérsico. Apesar da figura dos Aiatolás predominar no imaginário coletivo, a mulher iraniana passou a ser objeto de atenção também. Os olhares menos atentos situam todas as mulheres muçulmanas num mesmo contexto, sem distingui-las nas suas peculiaridades e nacionalidades. A mulher iraniana, porém, tem certas características que a tornam singular. É, portanto, esse aspecto menos aparente (para o Ocidente) da mulher iraniana que se mostrará no presente artigo, procurando esclarecer e fomentar o debate e pesquisas acerca do tema.

\section{ABSTRACT}

The Islamic Republic of Iran it's on the debates agenda all over the world. Since the beginning of the Iranian nuclear crises in 2005, all the eyes of the world turn into the middles eastern country situated between the Caspian See and the Persian Gulf. Despite the fact that the Ayatollahs figures that are always present in the collective imaginary, the Iranian woman became a focus of attention as well. Superficial regards place all the Muslim women in a same context, without distinguishing each ones nationalities and special aspects. But, the Iranian woman have certain characteristics that make them singular. It's this last evident aspect (to the western eyes) of the Iranian woman that will be showed in this article, aiming to clarifying and giving more subsidies for the debate regarding this issue.

\footnotetext{
${ }^{1}$ Advogada, Mestra em Direito pela Universidade de Coimbra; Pesquisadora do Núcleo de Pesquisa em Direito Público do Mercosul (NUPESUL) e do Núcleo de Estudos em Direito Internacional (NDI), ambos da UFPR; Professora universitária.
}

Revista Brasileira de Direito Internacional, Curitiba, v.6, n.6, jul./dez.2007 
Palavras-chave: mulher iraniana, revolução islâmica, liberdade.

Key words: Iranian woman, Islamic revolution, freedom. 


\section{INTRODUÇÃO}

Escrever sobre a mulher iraniana é muito gratificante, isto porque a ambigüidade que a caracteriza fascina. A mulher iraniana situa-se num espaço (temporal e físico) entre a modernidade e um passado de milênios impregnado de tradições -, entre a família e a profissão, entre uma moral rígida e a liberdade sexual. A mulher iraniana sonha com muitos símbolos do Ocidente e ao mesmo tempo refuta o que chama de depravação nos costumes ocidentais - tais como o consumo de drogas e sexo desmedido.

No Irã as mulheres são, como quase todas as muçulmanas ${ }^{2}$, obrigadas a cobrir-se com o véu em ambientes públicos. Entretanto, diferentemente da mulher afegã, por exemplo - que é obrigada a cobrir-se inteiramente deixando apenas uma abertura na altura dos olhos, e mesmo assim coberta com tecido de tela, para poder enxergar e que, por isso, são conhecidas como as mulheres sem rosto ${ }^{3}$-, a mulher iraniana goza da liberdade de deixar parte dos cabelos à mostra. Diferentemente da mulher árabe que não tem permissão para dirigir em hipótese alguma, a mulher iraniana tem total liberdade para isso; entretanto, as casadas devem ter autorização do marido, mas uma vez obtida a autorização, tem total liberdade para dirigir. ${ }^{4}$ Diferentemente das muçulmanas dos mais variados países que na maioria das vezes não tem permissão para freqüentar cinemas, as mulheres iranianas são elas próprias atrizes e diretoras cinematográficas. Dessa forma, como acentua Schouten, "As mulheres que

\footnotetext{
${ }^{2}$ Cumpre esclarecer que alguns países muçulmanos, como o Egito e a Turquia, por exemplo, não obrigam as mulheres a se cobrir. Entretanto, no Egito a maioria delas prefere usar o véu quando estão em público; já na Turquia o uso do véu é condicionado, sendo mesmo proibido em estabelecimentos escolares (sobretudo nas universidades públicas), nas repartições públicas e até mesmo no parlamento (Cf. SCHOUTEN, Maria Johanna. Modernidade e indumentária: as mulheres islâmicas. Texto disponível em <http://www,bocc.ubi.pt/pag/schouten-johanna-mulheres-islâmicas.pdf>. Acesso em 11 out. 2007).

${ }^{3}$ Este tipo de indumentária é conhecida pelo nome de burqa ou chador (tenda) e assumiu uma função de símbolo, sendo usada principalmente no Afeganistão e Paquistão. Entretanto, no imaginário da maioria dos ocidentais todas as mulheres muçulmanas usam este tipo de vestimenta, o que está muito longe de ser verdade (Cf. SCHOUTEN, Maria Johanna. Modernidade e indumentária: as mulheres islâmicas).

4 ARÊAS, Camila. Mulheres erguem nação dos aiatolás. Texto disponível em <http://www.abin.gov.br/modules/articles/print.php?id=705> . Acesso em 25 set. 2007.
}

Revista Brasileira de Direito Internacional, Curitiba, v.6, n.6, jul./dez.2007 
usam o véu têm em comum a profissão da fé islâmica, mas de resto, entre elas, podem existir grandes diferenças". ${ }^{5}$

Portanto, no país dos Aiatolás, embora predomine um código rígido de condutas, existem muitas coisas permitidas às mulheres. No plano internacional, o Irã não é Parte na Convenção das Nações Unidas sobre a Eliminação de Todas as Formas de Discriminação Contra as Mulheres. Contudo, a mulher iraniana, apesar de ainda sofrer forte discriminação, pode desfrutar de certas liberdades categoricamente negadas em outros países muçulmanos - sobretudo, de origem árabe. ${ }^{6} \mathrm{O}$ Irã é um país que em muitos aspectos desrespeita os direitos humanos; entretanto, foi uma iraniana a primeira mulher muçulmana a ganhar o prêmio Nobel da Paz, justamente por sua militância na área dos direitos humanos. Militância esta que, apesar de desagradar profundamente o regime, não é impedida de se realizar. Entretanto, muito embora a luta contra o desrespeito aos direitos humanos está a crescer, a mulher iraniana adúltera ou prostituta ainda é vítima da pena capital de morte por apedrejamento. A mulher iraniana, portanto, está mergulhada num mar de ambigüidades que a tornam única entre as muçulmanas.

Outro ponto a salientar, é que a população iraniana é extremamente jovem, $70 \%$ têm menos de trinta anos de idade. ${ }^{7}$ Portanto, a maioria das mulheres iranianas atualmente está nesta faixa etária. Tal fato faz com que elas sejam muito mais ousadas e desafiadoras que a geração de suas mães e avós, uma vez que a ousadia e o instinto rebelde são próprios da juventude. Por outro lado, ainda neste contexto, igualmente cumpre observar que $70 \%$ da população do Irã de hoje, portanto, ainda não havia nascido quando se deu a revolução islâmica. Este fato contribui para uma mudança de mentalidades tanto das mulheres como também dos próprios homens -, pois muitos aspectos que eram importantes para seus pais não significam nada (ou quase nada) para os jovens de hoje que, como qualquer jovem atualmente, quer se

\footnotetext{
${ }^{5}$ SCHOUTEN, Maria Johanna. Modernidade e indumentária: as mulheres islâmicas.

${ }^{6}$ Cumpre ressaltar que nem todos os países muçulmanos são árabes. O Irã, a Turquia, a Indonésia, o Paquistão, entre outros, não são árabes, porém, professam a religião muçulmana.

${ }^{7}$ CARRANCA, Adriana. Geração pós-revolução quer avanço. 03 set. 2007. Texto disponível em <http://www.estadao.com.br/estadaodehoje/20070903/not_imp45395,0.php>. Acesso em 26 out. 2007.
}

Revista Brasileira de Direito Internacional, Curitiba, v.6, n.6, jul./dez.2007 
relacionar com o mundo. Para estes jovens, não interessa o isolacionismo imposto pelo regime, eles querem comunicação e intercâmbio. Decorre daí que a mulher iraniana de hoje não se submete mais com tanta facilidade às restrições que lhes querem impor.

Dessa forma, a mulher iraniana vive uma situação paradoxal, onde sob muitos aspectos tem a mesma liberdade de uma mulher ocidental - como no acesso à universidade, por exemplo - e em outros casos pode ser submetida a leis dramaticamente bárbaras, como no caso da morte por apedrejamento. A política externa do governo iraniano, após a revolução islâmica, cerrou uma cortina e escondeu as mulheres do país atrás dela. Todavia, é esta cortina que o presente artigo propõe levantar, visando mostrar toda a riqueza e brilho escondidos por detrás do véu da mulher iraniana.

Revista Brasileira de Direito Internacional, Curitiba, v.6, n.6, jul./dez.2007 


\section{A MULHER IRANIANA APÓS A REVOLUÇÃO ISLÂMICA}

Para se compreender melhor o processo pelo qual passaram as mulheres iranianas nas últimas três décadas, faz-se necessário dividir o que ficou conhecido por "Revolução Islâmica" (a qual se deu em 1979) em dois momentos: o primeiro momento que vai desde os primeiros dias da revolução até a guerra Irã-Iraque; e o segundo momento que decorre após esta guerra. Tal divisão se justifica porque a guerra Irã-Iraque acarretou mudanças sensíveis na ordem interna iraniana e, portanto, é um marco na história do país no século $X X$.

\subsection{PRIMEIRO MOMENTO DA REVOLUÇÃO}

A República Islâmica do Irã é a herdeira do império persa, portanto, com uma história milenar e riquíssima. O povo iraniano, como todos os demais povos de cultura tão antiga, é extremamente orgulhoso de seu passado e das riquezas preservadas em seu território, que são consideradas patrimônio da humanidade. Assim, os vinte e oito anos que separam a revolução islâmica dos dias de hoje são apenas um pequeno fragmento na história deste país. Portanto, houve diversas épocas, em períodos anteriores, em que as mulheres iranianas gozaram de plena liberdade.

Assim sendo, o Irã está entre os primeiros países a emancipar a mulher; data de 1935 a sua emancipação. ${ }^{8}$ Até 1979 , ano da revolução, o país era governado pelo Xá Reza Pahlevi. O seu governo, apesar de extremamente corrupto e brutal (o que, aliás, foi um dos motivos para a sua deposição), procurou modernizar e ocidentalizar o país, o que desagradou profundamente os mulás (líderes religiosos). Todavia, as leis editadas em relação às mulheres

\footnotetext{
8 CARRANCA, Adriana. Um olhar feminino sobre o Irã. Vídeo. Disponível em $<$ http://www.estadao.com.br/interatividade/Multimidia/ShowVideos.action?destaque.idGuidSele ct=4B5E9E198C2D481BBE1C852322038D74> . Acesso em 26 out. 2007.
}

Revista Brasileira de Direito Internacional, Curitiba, v.6, n.6, jul./dez.2007 
estavam em muitos aspectos entre as melhores do mundo. ${ }^{9}$ Foi no seu governo que a mulher iraniana adquiriu o direito ao voto, por exemplo. ${ }^{10}$

Entretanto, em janeiro de 1979, os protestos da população contra os desmandos, corrupção e tirania do governo chegam ao seu ápice e o Xá é obrigado a deixar o país. O Aiatolá Ruhollah Khomeini que estava exilado em Paris, volta do exílio e assume o governo fundando uma república teocrática a única do gênero no mundo. ${ }^{11}$ Num primeiro momento a população deu apoio total ao novo governo; entretanto, não precisou muito tempo para que o regime começasse as perseguições e impusesse um rígido código de conduta, procurando banir do país os hábitos considerados ocidentais e, assim, voltar à pureza do islã. Dessa forma, foi imposto, além de outras coisas, um código de vestimenta (dress code) que apesar de atingir também os homens - estes foram proibidos de usar gravatas, uma vez que esta foi considerada um típico símbolo ocidental - foram as mulheres as maiores vítimas. O uso do véu, que não era obrigatório até então, foi imediatamente transformado em lei, através de uma fatwa - lei islâmica - ditada pelo Aiatolá Khomeini; e às mulheres foi exigido se cobrirem da cabeça aos pés quando em ambiente público, sendo que a cor preta passou a predominar; foram proibidas também de usar maquiagem e pintar as unhas. Elas passaram a usar o chador, porém, sem a necessidade de cobrirem completamente o rosto, como no caso das afegãs. No entanto, cumpre esclarecer que o uso do véu não foi considerado o problema em si, pois muitas mulheres nunca deixaram de usá-lo. O problema recaiu justamente no fato de terem tirado da mulher o seu poder de escolha, foi aí que se concentrou toda a revolta das iranianas. ${ }^{12}$

Entretanto, muitos outros direitos da mulher foram igualmente abolidos e a mulher iraniana passou a valer a metade de um homem. Num tribunal, por exemplo, precisa-se de duas mulheres para que seus testemunhos tenham o

\footnotetext{
${ }_{10}^{9} \mathrm{NAFISI}$, Azar. Lendo Lolita em Teerã: uma memória nos livros, 2004, p. 50. WIKIPÉDIA.

Disponível

em <http://pt.wikipedia.org/wiki/Revolu\%C3\%A7\%C3\%A3o_Iraniana>. Acesso em 22 out. 2007.

${ }_{11}$ KLINTOWITZ, Jaime. Sob o manto do fanatismo. Texto Disponível em <http://veja.abril.com.br/010300/p_044.html>. Acesso em 22 out. 2007.

${ }^{12}$ NAFISI, Azar. Lendo Lolita em Teerã: uma memória nos livros, p. 223.
}

Revista Brasileira de Direito Internacional, Curitiba, v.6, n.6, jul./dez.2007 
mesmo valor do testemunho de um homem. ${ }^{13} \mathrm{~A}$ mulher foi proibida de rir e de conversar com o sexo oposto em lugares públicos, e só sair à rua acompanhada do pai, irmão ou marido. Os lugares públicos foram estruturados de tal forma que as mulheres não ficassem no mesmo ambiente que o homem. A segregação igualmente foi exigida nos transportes públicos. Enfim, todos os costumes foram revistos e o braço da repressão baixou sobre as mulheres da República Islâmica.

As novas leis recaíram também sobre outras dimensões da vida das iranianas. A idade de casamento diminuiu de dezoito para nove anos e no caso de divórcio ficou determinado que a mulher não tem direito a nada e os filhos ficam sob a guarda do pai; e o apedrejamento voltou a ser a pena imposta à mulher adúltera ou à prostituta. ${ }^{14} \mathrm{O}$ novo regime, portanto, tirou das iranianas muitos direitos e a liberdade a que estavam habituadas. Todavia, há de se salientar que muitas das leis islâmicas só incidem sobre as mulheres casadas; dessa forma, como aponta Camila Arêas, a saída que as iranianas encontraram diante da repressão foi não se casarem ou então fazer um contrato de casamento, onde instituem as suas próprias regras. Assim sendo, a maioria das mulheres da região urbana passou a proceder dessa forma para fugir do rigor da lei. ${ }^{15}$

Todavia, novos ventos sopraram sobre a República Islâmica e em setembro de 1980 foi anunciada a guerra contra o Iraque. Estima-se que aproximadamente trezentos mil homens morreram nesta guerra. Esta guerra, contudo, paradoxalmente foi uma espécie de caminho para a liberdade da mulher iraniana, isto porque, com a maioria dos homens em idade ativa no campo de batalhas, o governo se viu obrigado a recrutar as mulheres para os serviços públicos. Terminada a guerra, em 1988, o governo não conseguiu fazê-las voltar para o recôndito de seus lares. Elas impuseram, de certa forma, o seu lugar ao sol.

${ }^{13}$ CARRANCA, Adriana. Uma voz feminina que desafia os aiatolás. Texto disponível em <http://www.estadao.com.br/estadaodehoje/20070903/not_imp45395,0.php>. Acesso em 26 out. 2007.

${ }_{14}^{14}$ NAFISI, Azar. Lendo Lolita em Teerã: uma memória nos livros, p. 50.

${ }^{15}$ ARÊAS, Camila. Mulheres erguem nação dos aiatolás.

Revista Brasileira de Direito Internacional, Curitiba, v.6, n.6, jul./dez.2007 
As iranianas sempre tiveram acesso à universidade. Assim sendo, elas ocuparam os mais variados cargos no setor público: Ministérios da Educação, Saúde, Minoria, Energia e Indústria e Mineração, onde as obrigações são de natureza tecnológica e industrial. No ano de 1986 chegou a 32,8\% a presença feminina no setor científico e de tecnologia, ${ }^{16}$ demonstrando com isso que às mulheres não ficaram destinadas somente ocupações inferiores. O governo se tornou no principal empregador da força de trabalho feminina. ${ }^{17}$ Todavia, não foi somente no setor público que as mulheres encontraram ocupação, o setor privado também as empregou. As iranianas, portanto, conquistaram importantes cargos não só no governo como também nas universidades e até mesmo na imprensa. ${ }^{18}$ Dessa forma, quando a guerra Irã-Iraque terminou, as mulheres estavam de tal forma estabelecidas em suas profissões que foi impossível para o governo mudar tal situação.

\subsection{SEGUNDO MOMENTO DA REVOLUÇÃO}

Com as mulheres constituindo $30 \%$ da força ativa do país no final da guerra, os rumos da República Islâmica tomaram uma direção completamente diversa dos demais países muçulmanos em que as mulheres são extremamente oprimidas e não raras vezes proibidas de trabalhar. Sendo digno de nota o fato de que o número de mulheres aprovadas em vestibulares aumentou regularmente ano após ano, de modo que atualmente mais de $60 \%$ dos graduados são do sexo feminino. ${ }^{19}$ Este fato por si só já demonstra a força das iranianas e o porquê de suas conquistas cada vez maiores na esfera pública.

Com o alto nível de escolaridade as iranianas aos poucos foram impondo as suas posições. Presentes em quase todos os setores, elas influenciaram no destino do país. Na década de 1990 conseguiram marcar o

\footnotetext{
${ }^{16}$ Texto disponível em <www. webiran.org.br/mulheres/mulheres_bot.htm>. Acesso em 22 out. 2007.

${ }_{17}^{17}$ ARÊAS, Camila. Mulheres erguem nação dos aiatolás.

${ }^{18}$ KLINTOWITZ, Jaime. Sob o manto do fanatismo.

${ }^{19}$ Texto disponível em <www. webiran.org.br/mulheres/mulheres_bot.htm>. Acesso em 22 out. 2007.
}

Revista Brasileira de Direito Internacional, Curitiba, v.6, n.6, jul./dez.2007 
seu espaço nos mais variados setores da sociedade. Dessa forma, apesar de o Irã ser um país muçulmano com um código de condutas rígido, como dito linhas atrás, a posição das mulheres não pode ser comparada às demais muçulmanas. Enquanto em outros países islâmicos, por exemplo, a mulher deve estar sempre posicionada atrás do homem, nos Jogos Olímpicos de Atlanta, em 1996, a primeira mulher iraniana a participar de uma olimpíada, depois da revolução islâmica, foi porta-estandarte da delegação (!). ${ }^{20}$ Aliás, no campo dos esportes as iranianas conquistaram espaço inimaginável no mundo islâmico. Elas praticam os mais variados esportes, claro que se thes exigem que estejam trajadas de modo "adequado", ou seja, elas são obrigadas a cobrir todas as partes do corpo, com exceção das mãos, rosto e os dedos dos pés. No entanto, se houver privacidade (sem homens ou fotógrafos a assistir), elas podem trajar-se como as ocidentais. ${ }^{21}$

Ainda quanto ao esporte, há um fato curioso sobre as iranianas. Após a revolução islâmica as mulheres foram proibidas de assistir aos jogos de futebol. Entretanto, apaixonadas pelo esporte-rei, as iranianas nunca se conformaram com tal proibição e sempre procuraram um modo de burlar a lei. Conforme relata Franklin Foer,

Com tanta gente passando pelas roletas do Azadi [principal estádio de Teerã], é impossível garantir sua conformidade aos aspectos mais estritos da lei islâmica. Os torcedores xingam na linguagem mais suja e claramente proibida. Fazem ataques verbais que não podem ser justificados por nenhuma interpretação do Corão. Alguns desses homens têm o rosto muito bem barbeado e usam roupas misteriosamente largas. Sob um olhar mais atento, percebe-se que não são realmente homens. Arriscando-se a punições severas, as mulheres de Teerã não conseguiram se afastar do Azadi. Deixam de lado os sutiãs, ocultam os cabelos longos, vestem-se como homens e se introduzem no estádio. ${ }^{22}$

Não podendo mais ignorar a paixão das iranianas pelo futebol, em 1987, o Aiatolá Khomeini revogou a proibição absoluta em relação à torcida

20 Texto disponível em <http://dossiers. publico.pt/noticia. aspx?idCanal=643\&id=138672>. Acesso em 15 out. 2007.

21 Texto disponível em <http://dossiers. publico.pt/noticia. aspx?idCanal=643\&id=138672>. Acesso em 15 out. 2007.

${ }^{22}$ FOER, Franklin; tradução de Carlos Alberto Medeiros. Como o futebol explica o mundo: um olhar inesperado sobre a globalização. Rio de Janeiro: Jorge Zahar, 2005, p. 189 e 190 (grifo desta autora).

Revista Brasileira de Direito Internacional, Curitiba, v.6, n.6, jul./dez.2007 
feminina. Ficava-lhes autorizado a assistir os jogos pela televisão, porém, a presença nos estádios continuava proibida. ${ }^{23}$

É interessante observar que um outro fato revelador da rebeldia da mulher iraniana, e da impotência do regime em contê-las, deu-se novamente por causa do futebol. Em 1997, após uma campanha difícil nas eliminatórias para a copa do mundo, a seleção iraniana, na partida decisiva contra a Austrália, conseguiu a classificação. O Irã iria à copa pela primeira vez depois da revolução. Fanáticas por futebol, as iranianas, como qualquer bom torcedor, queriam comemorar e, apesar dos apelos do governo que permanecessem em casa, milhares delas foram recepcionar os jogadores na volta para casa. Estes chegaram de helicóptero no estádio, porém, às iranianas não era permitida a entrada. Inconformadas elas desencadearam um processo que entrou para a história. Ainda segundo as palavras de Foer:

\begin{abstract}
Como relatou o antropólogo Christian Bromberger, quando a polícia se recusou a permitir que essas mulheres entrassem no estádio, elas começaram a gritar: "Não somos parte desta nação? Também queremos comemorar. Não somos formigas." Com medo da turba, a polícia deixou que três mil mulheres ocupassem assentos especiais, isolados do resto do estádio. Mas o que fazer com as duas mil, aproximadamente, do outro lado das roletas, que não tinham conseguido entrar no Azadi? O fato de as "queridas irmãs" terem entrado não foi suficiente para acalmá-las. Determinadas a também participar da comemoração, elas romperam a barreira policial e forçaram o caminho para dentro do estádio. Querendo evitar um grande tumulto que poderia canalizar as emoções cruas do momento numa direção perigosa, a polícia não tinha alternativa senão fazer vistas grossas à invasão e considerar-se derrotada. ${ }^{24}$
\end{abstract}

E conclui Foer, «Quando, no futuro, historiadores escreverem sobre a transformação no Oriente Médio, provavelmente se expressarão com lirismo sobre esse momento, que já se tornou conhecido como a "revolução do futebol"». ${ }^{25}$ De fato, foi nesse momento que o povo iraniano, impulsionado por suas mulheres, percebeu pela primeira vez que podia enfrentar o governo. E se

\footnotetext{
${ }^{23}$ FOER, Franklin. Como o futebol explica o mundo: um olhar inesperado sobre a globalização, p. 190.

${ }^{24}$ FOER, Franklin. Como o futebol explica o mundo: um olhar inesperado sobre a globalização, p. 192.

${ }^{25}$ FOER, Franklin. Como o futebol explica o mundo: um olhar inesperado sobre a globalização, p. 192.
}

Revista Brasileira de Direito Internacional, Curitiba, v.6, n.6, jul./dez.2007 
a polícia tivesse optado pela repressão pura e simples, talvez os jovens iranianos tivessem confirmado, pela própria experiência, 0 princípio constitucional de um Estado democrático de direito: "o poder pertence ao povo".

Como se pode observar, as mulheres iranianas estão muito à frente de suas outras irmãs muçulmanas. Elas estão presentes em muitas áreas totalmente proibitivas em outro país islâmico. ${ }^{26}$ Assim sendo, segundo as estatísticas, até 1995, o número de mulheres envolvidas com o cinema era de 900 e com a televisão era de 1800. Neste período também foram registrados a existência e dez revistas direcionadas às mulheres; $13 \%$ dos jornalistas do país era do sexo feminino, sendo que $22 \%$ delas estavam envolvidas com o setor de notícias. ${ }^{27}$ Assim sendo, pode-se afirmar que a mulher iraniana exerce, sem sombra de dúvida, a condição de agente na transformação do país e não a condição de um ser submisso esperando as ordens dos representantes masculinos, sejam estes parentes próximos ou o governo. Para Zahra Shojaei, presidente do Centro de Assuntos de Participação das Mulheres, da presidência da República, não há dúvidas de que "as mulheres construíram a cultura do país". ${ }^{28}$

Mas apesar de toda a participação da mulher iraniana no processo de desenvolvimento do país e do espaço conquistado na esfera pública, as pressões sobre ela, decorrentes de tradições patriarcais e machistas, ainda eram muito fortes. Porém, em 1997, foi eleito presidente do Irã um reformista, o filósofo e intelectual Mohammad Khatami, o qual teve um amplo apoio das

\footnotetext{
${ }^{26}$ Cumpre esclarecer que quando esta autora se refere aos países islâmicos de um modo geral, está excluindo a Turquia. Isto porque este país, embora muçulmano, está profundamente ocidentalizado e, por isso, muito das opressões impostas às mulheres não se aplicam na Turquia. Neste país o que se tem visto recentemente é justamente o fenômeno inverso, ou seja, muitas mulheres têm reclamado das regras que lhes são impostas para não usarem o véu. Uma deputada chegou a perder a sua cadeira no parlamento porque passou a usar o véu neste espaço público, pois queria chamar a atenção para a proibição às avessas do governo turco, por considerar tal imposição uma afronta à liberdade de expressão (Cf. SCHOUTEN, Maria Johanna. Modernidade e indumentária: as mulheres islâmicas).

${ }^{27}$ Texto disponível em <www. webiran.org.br/mulheres/mulheres_bot.htm>. Acesso em 22 out. 2007.

${ }^{28}$ Texto disponível em <www. webiran.org.br/mulheres/mulheres_bot.htm>. Acesso em 22 out. 2007.
} 
mulheres porque uma das suas plataformas políticas, durante a campanha eleitoral, foi a de melhorar a condição das mulheres na sociedade iraniana. ${ }^{29}$

Khatami governou o país de 1997 a 2005 e durante o seu governo muitas reformas foram realizadas. Com um espírito prático e uma forte consciência democrática, ele procurou construir um país moderno e conquistou muitos avanços no Estado de direito. Durante seus dois mandatos, Khatami permitiu que as novas gerações se formassem para o debate político e criassem uma nova correlação de forças na sociedade. Ainda há muito por ser feito, mas, como salienta Bernard Hourcade, "as noções de república, democracia, liberdade de expressão" foram exitosamente plantadas no seio da República Islâmica durante o seu governo. ${ }^{30}$

${ }^{29}$ Texto disponível em <http://pt.wikipedia.org/wiki/Mohammad_Khatami>. Acesso em 02 de nov. 2007.

${ }^{30}$ HOURCADE, Bernard. O despertar da esperança. In: Le Monde Diplomatique. Fevereiro, 2004. Texto disponível em <http://diplo.uol.com.br/imprima856>. Acesso em 22 out. 2007.

Revista Brasileira de Direito Internacional, Curitiba, v.6, n.6, jul./dez.2007 


\section{A SITUAÇÃO DA MULHER NO IRÃ DE HOJE}

À luz de tudo o que se escreveu nas seções precedentes deste artigo, constata-se que a mulher iraniana neste início do século XXI é muito diferente daquela do período pós-revolucionário, quando os seus direitos e liberdade foram restringidos. Hoje no Irã as mulheres mostram-se mais ousadas e desafiadoras; os seus véus estão mais coloridos e a cor preta que predominou durante pelo menos duas décadas deu lugar as mais diversas cores; as suas túnicas também estão muito mais curtas; elas igualmente passaram a usar maquiagem e a andar nas ruas com homens que não são necessariamente seus pais, irmãos ou maridos. ${ }^{31}$ Não há dúvidas de que esta nova postura da mulher iraniana é um desafio para o regime teocrático dos Aiatolás.

Todavia, cumpre observar quanto à vestimenta que, apesar da crença geral derivada de informações distorcidas, a mulher iraniana nunca foi proibida de usar calças compridas, por exemplo. É verdade que no início da revolução foram obrigadas a usar o chador por cima de suas roupas quando estivessem em público; mas, no entanto, pouco a pouco foram deixando de lado este tipo de vestimenta, sobretudo após a ascensão do presidente Khatami ao poder, e hoje o véu, cada vez mais colorido, cobre apenas parte de seus cabelos. $\mathrm{Na}$ verdade o que se exige atualmente é que a mulher use uma túnica larga (para não marcar o corpo) que vá, pelo menos até a metade da coxa - que cubra os quadris - e as mangas devem ser compridas. Dessa forma, a mulher iraniana pode usar uma calça jeans normalmente - o que elas fazem literalmente e de preferência calças de marca como Benetton ou Gucci. Assim, deve-se cair por terra a imagem comum que se tem de uma mulher vestida de preto, coberta da cabeça aos pés. De fato, mulheres vestidas dessa maneira existem na República Islâmica, mas geralmente são mulheres mais velhas ou de famílias muito conservadoras. As iranianas na verdade são muito vaidosas e desde a

\footnotetext{
${ }^{31}$ NAFISI, Azar. Lendo Lolita em Teerã: uma memória nos livros, p. 491.
}

Revista Brasileira de Direito Internacional, Curitiba, v.6, n.6, jul./dez.2007 
revolução, pelo menos trinta mil já fizeram cirurgia plástica para correção de nariz. $^{32}$

Mas não é só na maneira de se vestir que as iranianas avançaram. Em muitos outros aspectos elas também deram o salto para uma maior liberdade e direitos garantidos. Um exemplo é o da advogada Shirin Ebadi, que ganhou o prêmio Nobel da Paz, em 2003, em virtude da sua militância na área dos direitos humanos. Shirin Ebadi foi a primeira muçulmana a ser escolhida pelo parlamento norueguês - que indica o vencedor do Prêmio Nobel da Paz. Sua história de vida é riquíssima, ela foi a primeira juíza mulher na história do Irã; assumiu este cargo antes de 1979, porém após a revolução foi impedida de atuar no judiciário. Hoje trabalha como advogada independente e criou uma organização que luta pelos direitos humanos. ${ }^{33}$

Apesar das leis islâmicas favorecerem imensamente o homem, contudo não fecharam as portas das escolas às mulheres e, conseqüentemente, as iranianas, seguindo uma tendência mundial, ocupam atualmente $67 \%$ das vagas nas universidades e já representam metade da força de trabalho no país. Elas estão presentes nas mais diversas áreas: são jornalistas, advogadas, cineastas, taxistas, pilotos de avião, jogadoras de futebol, ${ }^{34}$ economistas, parlamentares. Com a revolução tecnológica, elas também ganharam voz; hoje no Irã existem aproximadamente 70 mil blogs, os quais colocaram o farsi entre os dez idiomas mais usados na Internet, entretanto, a maioria desses blogs são feitos por mulheres. ${ }^{35}$ Tal ferramenta dá um poder incalculável às iranianas, colocando-as num diálogo direto entre 0 público e o privado, dando-Ihes a oportunidade de expressarem publicamente os seus pensamentos e anseios.

32 CARRANCA, Adriana. Iranianas em busca de igualdade. Texto disponível em <http://www.estadao.com.br/estadaodehoje/20070903/not_imp45395,0.php>. Acesso em 26 out. 2007.

${ }^{33}$ CARRANCA, Adriana. Uma voz feminina que desafia os aiatolás.

${ }^{34} \mathrm{Em}$ abril de 2006, o presidente Mahmoud Ahmadnejad, revogou a proibição das mulheres freqüentarem os estádios de futebol. Elas agora podem assistir aos jogos nos estádios, porém em setores separados dos homens. O presidente garantiu, entretanto, que a elas serão destinados, apesar da segregação, os melhores lugares nos estádios. Texto disponível em <http://www1.folha.uol.com.br/folha/esporte/ult92u100682.shtml>. Acesso em 28 de out. 2007.

${ }^{35}$ CARRANCA, Adriana. Iranianas em busca de igualdade.

Revista Brasileira de Direito Internacional, Curitiba, v.6, n.6, jul./dez.2007 
Um outro exemplo da atuação da mulher iraniana é Nazanin Azar, de 36 anos. Segundo reportagem de Adriana Carranca, ela sustenta a casa e os filhos, depois de ter se divorciado do marido. Numa iniciativa ousada, juntou-se com outras cento e cinqüenta mulheres para abrir uma cooperativa de motoristas de táxi para uma clientela exclusivamente feminina. Ela costuma transportar "jovens arrumadas para festas, que usam o seu táxi para evitar o assédio dos homens". ${ }^{36}$

A cineasta Manijeh é outra iraniana, apresentada na reportagem de Adriana Carranca, que conseguiu se impor. Em entrevista à jornalista brasileira, disse que já produziu vinte e cinco filmes, apesar de toda a dificuldade encontrada por causa dos censores do governo. O seu primeiro filme foi "Prisão de Mulheres", que relata a vida das presas em Teerã. Este filme foi proibido no Irã; entretanto, Manijeh enviou cópias ao exterior e o filme foi exibido em mais de oitenta festivais e acabou conquistando sete prêmios. ${ }^{37}$

Uma outra prática presente nas sociedades muçulmanas e, portanto, na iraniana não é exceção, é a poligamia. O homem pode ter mais do que uma esposa, porém, à mulher é terminantemente proibido agir do mesmo modo. Entretanto, no Irã a lei avançou também nessa questão, pois, desde 1992, a mulher pode pedir uma compensação em dinheiro se o marido quiser exercer o seu direito à poligamia. A edição desta lei acabou, dessa forma, por restringir esta prática. ${ }^{38}$

A mulher iraniana hoje tem o seu espaço, conquistado paulatinamente no decorrer de quase três décadas. Assim sendo, como alerta a antropóloga iraniana Ziba Mir-Hosseini, o maior desafio para a mulher iraniana atualmente, além da luta contra a repressão do regime (que, apesar de mais branda ainda continua), é fazer com que a lei reconheça a sua posição e participação na esfera pública, pois, "quando a lei não corresponde à realidade, não é seguida". ${ }^{39}$ Cabe lembrar que a maioria das iranianas de hoje tem menos de trinta anos de idade e, portanto, pertencem a uma geração com os olhos

\footnotetext{
${ }^{36}$ CARRANCA, Adriana. Iranianas em busca de igualdade.

${ }^{37}$ CARRANCA, Adriana. Iranianas em busca de igualdade.

${ }^{38}$ ARÊAS, Camila. Mulheres erguem nação dos aiatolás.

${ }^{39}$ Apud ARÊAS, Camila. Mulheres erguem nação dos aiatolás.
}

Revista Brasileira de Direito Internacional, Curitiba, v.6, n.6, jul./dez.2007 
voltados para o futuro e por isso exige mudanças. Ainda fazendo uso das palavras da antropóloga Ziba Mir-Hosseini:

O Irã está muito à frente. No Marrocos as mulheres têm melhores leis,
mas na prática são $80 \%$ de analfabetas e poucas no trabalho (...). O Irã
é o inverso: o governo tradicional enfrenta o secularismo da sociedade
educada e habituada a idéias liberais. São 100 anos de Constituição e
30 de falhas da revolução islâmica. A sociedade tenta se encontrar,
mas negocia sua identidade com a religião. ${ }^{40}$

Em sua luta pela igualdade, contudo, as iranianas nos últimos anos passaram a receber apoio dos religiosos modernistas, que procuram abrandar as imposições do regime sobre a mulher, nomeadamente o uso do véu. Estes religiosos buscam transformar a República Islâmica num país moderno, onde as mulheres não sofram tantas restrições. $O$ atual líder supremo, o Aiatolá Ali Khamenei, já demonstrou sua intenção de promover uma nova interpretação da lei islâmica em favor dos direitos das mulheres. ${ }^{41}$

Assim sendo, na atual conjuntura, apesar da forte campanha do Ocidente contra o Irã, em virtude principalmente de seu projeto nuclear, podese afirmar, como observa Bernard Houcarde, que este país é o único no Oriente Médio, em decorrência das características das iranianas (cultas e com formação superior sólida e com espaço nas mais diversas áreas profissionais), com condições de provocar uma revolução na situação da mulher muçulmana e, por conseguinte, propagá-la por todo o restante dos países da região. ${ }^{42}$ Isto pode muito bem vir a acontecer, pois as iranianas são, usando as palavras de Jaime Klintowitz,

(...) as mulheres com maior atividade política no Golfo Pérsico, e talvez no mundo islâmico". (...) O fracasso da única teocracia deu impulso a novas formulações sobre o Estado islâmico moderno. Muitas das discussões mais profundas dentro do islã estão ocorrendo nos jornais, tribunais e salas de aula iranianas. Mesmo clérigos e intelectuais que foram próximos a Khomeini estão agora colocando em dúvida as bases do pensamento religioso sobre o qual construíram a República Islâmica. A luta dos iranianos para liberalizar o regime

\footnotetext{
${ }^{40}$ Apud ARÊAS, Camila. Mulheres erguem nação dos aiatolás.

${ }^{41}$ ARÊAS, Camila. Mulheres erguem nação dos aiatolás.

${ }^{42}$ HOURCADE, Bernard. O despertar da esperança. In: Le Monde Diplomatique.
} 
(ninguém sugere publicamente que a teocracia pode ser abolida) é um dos movimentos mais fascinantes da virada do milênio. Ao derrubar o Xá, Khomeini atingiu pela primeira vez na História moderna o objetivo comum a todos os muçulmanos: tomar o poder político em nome de Alá. A atual geração está tentando devolver o poder político ao povo, sem precisar jogar Alá pela janela. ${ }^{43}$

Como visto, há o despertar de uma nova consciência no Irã de hoje e à mulher iraniana cabe um papel fundamental no futuro desenvolvimento do país. Aliás, hoje é fato aceite pelos estudiosos que nenhum país pode atingir o desenvolvimento pleno sem a participação feminina na esfera pública. Finalmente a condição de agente das mulheres começa a receber atenção, não apenas nos fóruns internacionais sobre a mulher, mas também pelos próprios governos. Nesse novo contexto, como ressalta Amartya Sen, cabe um novo papel às mulheres:

Já não são mais receptoras passivas de auxílio para melhorar seu bemestar, as mulheres são vistas cada vez mais, tanto pelos homens como por elas próprias, como agentes ativos de mudança: promotoras dinâmicas de transformações sociais que podem alterar a vida das mulheres e dos homens. ${ }^{4{ }^{3}}$

Isto não quer dizer, contudo, que a luta contra a opressão e violência contra a mulher tenha sido deixada em segundo plano. Pelo contrário, atualmente a luta é para que, paralelamente a uma melhor condição de vida das mulheres em sociedades opressoras, seja-lhes reconhecido também o papel de agente ativo no processo de desenvolvimento. Amartya Sen lembra ainda que:

Trabalhos empíricos recentes evidenciaram o modo como o respeito e a consideração pelo bem-estar das mulheres são acentuadamente influenciados por variáveis como o potencial das mulheres para auferir uma renda independente, encontrar emprego fora de casa, ter direitos de propriedade, ser alfabetizadas e participar como pessoas instruídas nas decisões dentro e fora da família. ${ }^{45}$

\footnotetext{
${ }^{43}$ KLINTOWITZ, Jaime. Sob o manto do fanatismo.

${ }^{44}$ SEN, Amartya Kumar. Desenvolvimento como liberdade. tradução Laura Teixeira Motta; revisão técnica Ricardo Doniselli Mendes. Desenvolvimento como liberdade. São Paulo: Companhia das Letras, 2000, p. 220.

${ }^{45}$ SEN, Amartya Kumar. Desenvolvimento como liberdade, p. 222.
} 
A mulher iraniana ainda sofre muitas restrições e muitas das liberdades apontadas por Sen ainda Ihes são negadas. Entretanto, por outro lado, ela já conquistou muito espaço, que muçulmanas de outros países jamais sonharam. A conquista da mulher iraniana no mercado de trabalho e a sua elevada instrução fazem com que ela reúna em si todas as condições para ser a promotora das mudanças no mundo muçulmano. Essa condição de agente da mulher iraniana que já existe na prática, como demonstrado no decorrer deste estudo, uma vez que atualmente responde por $50 \%$ da força de trabalho no Irã, tem, de fato, grandes probabilidades de vir a influir por todo o restante do Oriente Médio. Aí reside toda a singularidade e força da mulher iraniana. 


\section{CONSIDERAÇÕES FINAIS}

Como mencionado no início deste artigo, os olhos do mundo todo estão atualmente voltados para a República Islâmica, em decorrência do seu projeto nuclear. Com receio de que o Irã utilize a tecnologia do enriquecimento do urânio para construir a bomba atômica, desencadeou-se uma campanha global contra o país e os seus aspectos negativos são exacerbadamente apontados pela mídia. Dentre estes aspectos costuma-se indicar a condição feminina na sociedade iraniana e, deliberadamente ou não, as imagens que chegam até o Ocidente são de mulheres vestidas de preto, completamente cobertas. Entretanto, conforme foi visto no decorrer deste estudo, este estereótipo está muito longe de representar a mulher iraniana, sobretudo a mulher iraniana do início do século XXI.

Apesar de muçulmanas e de sofrerem forte pressão do regime, as iranianas não se comparam com o restante de suas irmãs de fé. Pelo contrário, são mulheres que se destacam no contexto do Oriente Médio por causa de sua elevada formação e presença significativa no mercado de trabalho, exercendo os mais variados tipos de profissão.

A maioria das mulheres do Irã atualmente tem menos de trinta anos de idade. Tal fato acarreta mudanças profundas no sistema, pois uma população extremamente jovem tem outras expectativas e exigências, seus olhos estão voltados para o futuro. A juventude das iranianas ligada à atual revolução tecnológica abre as portas para novos horizontes e os Aiatolás, donos do poder, estão atentos para isso.

Mas, apesar de avanços significativos, a mulher iraniana ainda tem de se submeter a leis retrógradas. O exemplo mais contundente é a pena de morte por apedrejamento da mulher adúltera ou da prostituta. Em caso de divórcio perde a guarda dos filhos e não tem direito a qualquer espécie de pensão. À mulher casada é exigido a autorização do marido para o exercício de uma série de atividades e, por isso, a saída encontrada pelas iranianas é não se casarem. Na verdade, muitas das leis vigentes no país não são seguidas, tanto as mulheres como os próprios homens procuram meios de burlá-las, pois 
tais leis não correspondem à realidade. O que acontece hoje no Irã é que sua sociedade está muito mais à frente do que o seu sistema legal. E como bem salientou a antropóloga Ziba Mir-Hosseini, o maior desafio para as iranianas hoje é fazer com que a lei reconheça as suas conquistas e a sua consagração na esfera pública. ${ }^{46}$

As iranianas atualmente constituem $50 \%$ da força de trabalho da República Islâmica, e há de se destacar que esta força de trabalho é altamente qualificada, colocando-as não raras vezes em posição de destaque. Tal fato as transformou em agentes ativos no processo de desenvolvimento do país. As iranianas, portanto, não estão na posição submissa de esperar que os outros promovam o seu bem-estar; pelo contrário, a mulher iraniana de hoje é ela própria a promotora das mudanças em seu meio. Esta posição faz com que ela possa influir em todos os setores da sociedade, seja econômico, social, cultural ou político.

No atual contexto do Oriente Médio, a mulher iraniana se sobressai. $\mathrm{O}$ Irã, sem sombra de dúvida, pode ser considerado a maior potência muçulmana da região e a sua posição estratégica, o seu contexto histórico, político e internacional não pode ser menosprezado. E essa dinâmica deve-se, principalmente, ao fato de que, após a revolução islâmica, o governo não escondeu suas mulheres em casa, relegando-lhes um papel secundário. Pelo contrário as iranianas foram chamadas às escolas e ao mercado de trabalho. Isso fez com que o país se desenvolvesse de forma singular no mundo muçulmano.

Filhas da revolução de 1979, as mulheres iranianas do início do século XXI estão com os pés fincados no futuro. Consideradas por muitos analistas os agentes mais eficientes da sociedade islâmica, hoje elas lutam pelo reconhecimento legal de suas conquistas no espaço público. A partir do momento em que se transformaram em agentes no processo de desenvolvimento, elas deram início, paralelamente, ao processo de mudança em sua condição de mulher. Esse processo de mudança dentro do seu próprio meio pode vir a se alastrar por todo o mundo muçulmano. Portanto, essa

${ }^{46}$ Apud ARÊAS, Camila. Mulheres erguem nação dos aiatolás.

Revista Brasileira de Direito Internacional, Curitiba, v.6, n.6, jul./dez.2007 
posição da mulher iraniana pode fazer a diferença; e a transformação do Oriente Médio numa grande democracia e sociedade mais aberta tem grandes chances de se realizar por meio da mulher, mais particularmente, por meio da mulher iraniana. 


\section{REFERÊNCIAS}

ARÊAS, Camila. Mulheres erguem nação dos aiatolás. Texto disponível em $<$ http://www.abin.gov.br/modules/articles/print.php?id=705>. Acesso em 25 set. 2007.

CARRANCA, Adriana. Geração pós-revolução quer avanço. Disponível em <http://www.estadao.com.br/estadaodehoje/20070903/not_imp45395,0.php>. Acesso em 26 out. 2007.

CARRANCA, Adriana. Iranianas em busca de igualdade. Texto disponível em <http://www.estadao.com.br/estadaodehoje/20070903/not_imp45395,0.php>. Acesso em 26 out. 2007.

CARRANCA, Adriana. Um olhar feminino sobre o Irã. Vídeo. Disponível em <http://www.estadao.com.br/interatividade/Multimidia/ShowVideos.action?desta que. idGuidSelect=4B5E9E198C2D481BBE1C852322038D74>. Acesso em 26 out. 2007.

CARRANCA, Adriana. Uma voz feminina que desafia os aiatolás. Entrevista com Shirin Ebadi. Texto disponível em

<http://www.estadao.com.br/estadaodehoje/20070903/not_imp45395,0.php>. Acesso em 26 out. 2007.

FOER, Franklin; tradução de Carlos Alberto Medeiros. Como o futebol explica o mundo: um olhar inesperado sobre a globalização. Rio de Janeiro: Jorge Zahar, 2005.

HOURCADE, Bernard. O despertar da esperança. In: Le Monde Diplomatique. Fevereiro, 2004. Texto disponível em <http://diplo.uol.com.br/imprima856>. Acesso em 22 out. 2007.

KLINTOWITZ, Jaime. Sob o manto do fanatismo. Texto Disponível em <http://veja.abril.com.br/010300/p_044.html>. Acesso em 22 out. 2007.

NAFISI, Azar; tradução de Tuca Magalhães. Lendo Lolita em Teerã: uma memória nos livros. São Paulo: A Girafa, 2004.

SCHOUTEN, Maria Johanna. Modernidade e indumentária: as mulheres islâmicas. Texto disponível em <http://www,bocc.ubi.pt/pag/schouten-johannamulheres-islâmicas.pdf>. Acesso em 11 out. 2007.

SEN, Amartya Kumar; tradução Laura Teixeira Motta; revisão técnica Ricardo Doniselli Mendes. Desenvolvimento como liberdade. São Paulo: Companhia das Letras, 2000.

WIKIPÉDIA - A enciclopédia livre. Disponível em <http://pt.wikipedia.org/wiki/Revolu\%C3\%A7\%C3\%A3o_Iraniana>. Acesso em 22 out. 2007. 
http://dossiers. publico.pt/noticia.aspx?idCanal=643\&id=138672

http://www1.folha.uol.com.br/folha/esporte/ult92u100682.shtml

www.webiran.org.br/mulheres/mulheres_bot.htm

Revista Brasileira de Direito Internacional, Curitiba, v.6, n.6, jul./dez.2007 